\title{
水面上に風シアーが存在する開水路流れ場における 水·空気層乱流構造に関する基礎的研究
}

\author{
襧津家久 $1 \cdot$ 吉田圭介 ${ }^{2} \cdot$ 牛島省 ${ }^{3}$ \\ 1フェロー 工博 京都大学大学院教授 社会基盤工学専攻 (T606-8501 京都市左京区吉田本町) \\ 2学生員 工修 京都大学大学院 環境地球工学専攻博士課程（同上) \\ 3正会員 工博 京都大学大学院助教授 社会基盤工学専攻（同上）
}

\begin{abstract}
水面上に風シアーが存在する開水路流れ場 (水·空気 2 層流) を対象として，水路中央鉛面断面における水・空気 流をレーザー流速計(LDA)で2次元乱流計測を行い，両層の乱流構造に関して実験的に検討した. その結果, 底面シ アーが卓越するケースでは空気層および水層ともに対数則が成立し，乱れ強度は普遍関数に従うことが判明した。一 方, 風シアーが晫越るケースでは乱強度は界面近傍で増大し，レイノルズ応力は界面近くで負值を有することが わかった. これは波動成分の影響であることを説明できた。
\end{abstract}

Key Words: air-water open-channel flows, turbulent structure, air sheartwater shear, LDA

\section{1. 緒言}

緩勾配河川流れでは水流上の風の影響が無視できない 場合がある.また，湖沼や海岸・海洋では界面近傍にお ける風シアーの界面近傍流体挙動への影響が水底面シア 一よりも相対的に大きくなる場合も知られ，精力的に研 究されている. たとえば，閉鎖性水域における吹送流は 密度成層に擾乱を起こし, 水面を通しての熱の交換や水 層内の流体混合を引き起こすことが知られ，水面上の風 応力の効果について研究がなされている゙2). 一方, 地球 温暖化問題の原因である温室効果ガスの気液界面を通し た輸送現象については，それらガスのシュミット数が比 較的大きく, 分子搪散輸送よりも乱流輸送の方が現象を 支配していることが指摘され゙)，水面シアーによる界面近 傍の乱れ挙動を解明することが重要である.

水・空気 2 層流場での乱流構造を検討する場合, 従来 よりまず水流および空気流の流速分布の予測が精力的に 行われてきた. 界面空気流に関しては主に海岸・海洋工 学の分野で研究がなされ, 粗度高さと風速分布の関連性 についての研究が数多く行われてきた. 流速分布を決定 する上では混合距離をいかに合理的にモデル化するかが 重要であるという点から, Riley et al. ${ }^{4}$ はvan Driest による 滑面境界層の混合距離モデル，Rotta による粗面境界層の モデルとの比較から，風波上での混合距離モデルを提案 している. 一方, 水流に関しては Reid" ${ }^{5}$ 開水路流水の水
面上に風シアーが働いた場合について水中のせん断応力 を直線分布と仮定し混合距離が水樑方向に放物線になる と考えて，底面シアーおよび界面シアー（風シアー）の 比に応じた流速分布の式を導いている．しかし，開水路 の混合距離とせん断応力を仮定して流速分布を求める場 合には予測誤差を生じる可能性がある.これに対して鶴 谷けは底面および水面からそれぞれ対数則が成立すると仮 定して境界条件と連続式の条件から 2 つ対数則を結び つけた流速分布を提案し, 実験值と比較的一致すると指 摘している. さらにHughes and Duffey ${ }^{7}$ ( 1 無次元流速公配 式を数值積分することで Reid の式を拡張した一般形を求 め，底面シアーと界面シアーの相対的な大きさや界面で の渦粘性の減衰度合いに応じた流速分布の比較を行って いる. 最近, 中山・襧津 ${ }^{8}$ は, 水・空気 2 層流の乱流構造 をレーザー流速計で計測している.

乱れ強度分布に関して, 鶴谷のは水面上に風が吹いてい る場合について底面から発達する乱れ強度と水面からの 乱れ強度を線形的に加えることができると仮定して経験 式を与えた. また, 中山・䨖津は鶴谷の線形経験則を検 討し，底面シアーに対する界面シアーの比が大きくなる と乱れの非線形効果が大きくなることを明らかにした.

一方，著者ら”は閉鎖性領域における風波場の乱流構造に 関して，水・空気層の同時計測を行い，その相互作用に つて論じた.

以上, 既往の研究では水・空気 2 層流に関して, 各層 の平均流速特性や乱れ特性について論じられてきたが, 
表-1 水理条件表

\begin{tabular}{|c|c|c|c|c|c|c|c|c|c|c|}
\hline \multicolumn{2}{|c|}{ Case } & $h_{w}$ & $\underset{(\mathrm{cm})}{B}$ & $\underset{(\mathrm{cm})}{h_{a}}$ & $\underset{(1 / s)}{Q}$ & $F \boldsymbol{r}$ & $U_{a, \max }$ & $\begin{array}{c}U_{* a} \\
(\mathrm{~cm} / \mathrm{s})\end{array}$ & $\begin{array}{l}U_{*_{w}} \\
(\mathrm{~cm} / \mathrm{s})\end{array}$ & $\begin{array}{c}U_{* b} \\
(\mathrm{~cm} / \mathrm{s})\end{array}$ \\
\hline \multirow{3}{*}{ Open } & $\mathrm{C} 01$ & \multirow{15}{*}{7} & \multirow{15}{*}{40} & \multirow{15}{*}{43} & 4.64 & 0.2 & $\ldots$ & $\ldots$ & $\cdots$ & 0.56 \\
\hline & $\mathrm{CO} 2$ & & & & 11.6 & 0.5 & -.-- & -..- & -..- & 1.132 \\
\hline & $\mathrm{CO} 3$ & & & & 18.6 & 0.8 & $\ldots$ & -..- & $\ldots$ & 1.788 \\
\hline \multirow{3}{*}{ Wind } & $\mathrm{ClO}$ & & & & $\ldots$ & 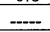 & 1.11 & 5.023 & 0.189 & $\ldots$ \\
\hline & $\mathrm{C} 20$ & & & & $\ldots$ & ---- & 2.54 & 10 & 0.369 & $\ldots$ \\
\hline & C30 & & & & - & ...- & 3.93 & 17.38 & 0.631 & $\ldots$ \\
\hline \multirow{9}{*}{ Combined } & $\mathrm{Cll}$ & & & & 4.64 & 0.2 & 1.11 & 4.43 & - & 0.484 \\
\hline & $\mathrm{C} 12$ & & & & 11.6 & 0.5 & 1.11 & 4.35 & ב-ב-ב & 1.046 \\
\hline & $\mathrm{C} 13$ & & & & 18.6 & 0.8 & 1.11 & 3.94 & $\ldots$ & 1.689 \\
\hline & $\mathrm{C} 21$ & & & & 4.64 & 0.2 & 2.54 & 10.58 & 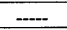 & 0.414 \\
\hline & $\mathrm{C} 22$ & & & & 11.6 & 0.5 & 2.54 & 9.1 & -.... & 0.959 \\
\hline & $\mathrm{C} 23$ & & & & 18.6 & 0.8 & 2.54 & 9.23 & $\ldots$ & 1.615 \\
\hline & $\mathrm{C} 31$ & & & & 4.64 & 0.2 & 3.93 & 16.77 & $\ldots$ & 0.492 \\
\hline & C32 & & & & 11.6 & 0.5 & 3.93 & 15.58 & ב-- & 0.964 \\
\hline & $\mathrm{C} 33$ & & & & 18.6 & 0.8 & 3.93 & 13.57 & ב--- & 1.554 \\
\hline
\end{tabular}

両層の乱流構造および界面変動特性を同時に検討したも のはあまりなく，水層内の流体特性は不明な点が多い． そこで，本研究は水面上に風シアーが存在する開水路流 れ場（水・空気 2 層流）を対象として，系統的に実験条 件を変化させて，水路中央鉛直断面における水・空気流 をレーザー流速計(LDA)で 2 次元計測を行い，両層の乱流 構造に関して実験的に検討を行う。

\section{2. 実験装置および水理条件}

\section{(1) 実験水路}

本実験で用いた水路は，全長 $16 \mathrm{~m} ，$ 幅 $40 \mathrm{~cm}$ ，高さ $50 \mathrm{~cm}$ の風洞水槽である. 図-1に概要図を示す．計測部は空気 流吹き出し口から $9 \mathrm{~m}$ 下流の地点で, 水路両䚋壁と底面が 光学ガラス製で, LDA 計測が容易にできる. また, 水路 下には油圧ジャッキがあり，水路勾配を任意に変化でき る. 下流端には消波材を設置し風波の下流端反射を抑制 した.

\section{(2) 計測方法}

瞬間流速の点計測には， $300 \mathrm{~mW}$ の後方散乱型 2 成分ア ルゴンイオンレーザー流速計(LDA，Dantec 社製)を用いた

（図-2）. 計測点は水層および空気層それぞれの水路中 央断面とした. 空気流の LDA 散乱粒子の直径は平均 $1.5 \mu \mathrm{m}$ ，比重は1.02であり，霧発生装置(Dantec 社製)を用 いた. 水流の LDA 散乱粒子には市販の水性ペンキを用い た. LDA のトラバース装置は水路に直付けで $1 / 100 \mathrm{~mm}$ の 精度を有する. 測定時間は60秒, 測定周波数は水層で約 $200 \mathrm{~Hz}$ ，空気層で約 $500 \mathrm{~Hz}$ であった. 総サンプルデータ数 は計測1点あたり 12000 個以上とした．座標系は水路中央 断面において，流下方向に $x$ 軸，鉛直上向きに静水面汃 ら $y$ 軸，水路底面から上向きに $z$ 軸とした（図-2）。流 下方向 $x$ 軸および鉛直方向 $y$ 軸 $(z$ 軸)方向の平均流速成 分を $(U, V)$, 乱れ変動成分を $(u, v)$ と定義した. また,

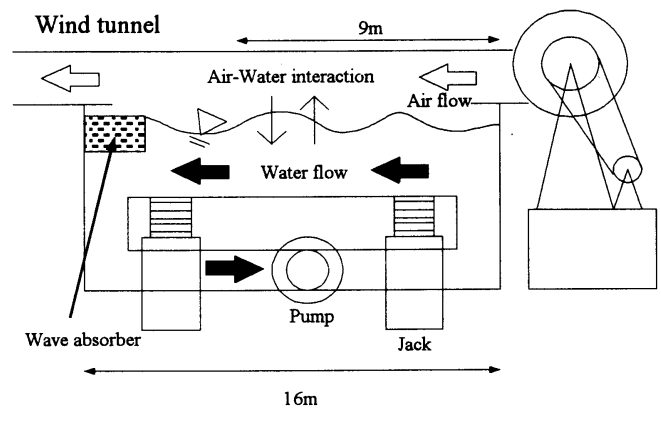

図-1 風洞水槽実験装置

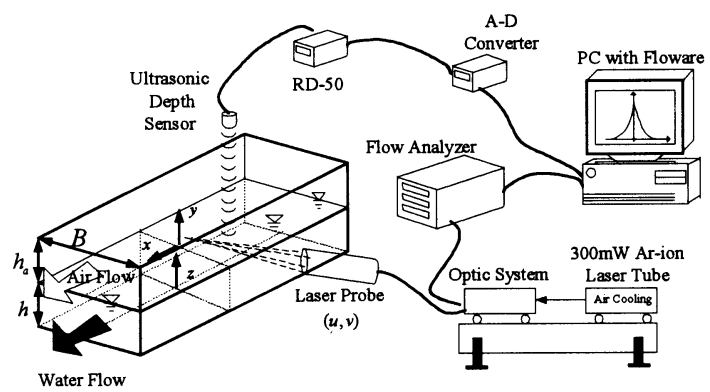

図-2 LDA 計測装置

流速計測部の鉛直上方に超音波波高計(Keyence 社製)を設 置して流速変動と水面変動の同時計測を行った。ささらに, 吹送流の表面流速 $U_{s}$ の測定には, 約 $3 \mathrm{~mm}$ 径のフロート が $30 \mathrm{~cm}$ 移流する時間を計測し, 最低30サンプル以上で平 均して算出した.

\section{(3) 実験条件}

実験条件を表-1に示す，実験条件は(A)底面シアーの卓 越する開水路流れ(OPEN)，(B)風による界面シアーが卓越 する風波流れ(WIND), (C) 両者が混在する混成流れ (COMBINED) と分類し， 3 種類行った. 水深 $h_{w}$ および空 気層厚 $h_{a}$ を固定し, 水路底面は平滑とした. また, 3 通 りの開水路等流を作るため, 水流のフルード数に合わせ 


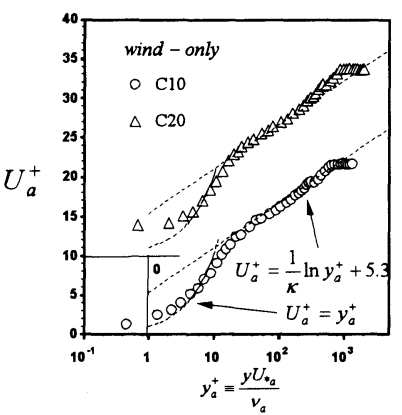

図-3 風波場の空気層平均風速 $U a$ (滑面内部変数表示)

(C20 のデータは縦軸を 10 ずつ上方へ 平行移動して表示)

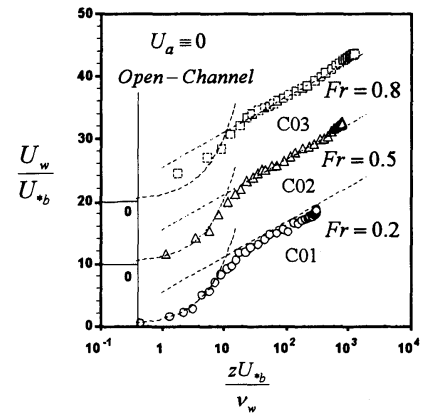

図-6（a）開水路場の水層平均流速 $U_{w}$

(データは10ずつ上方へ平行移動)

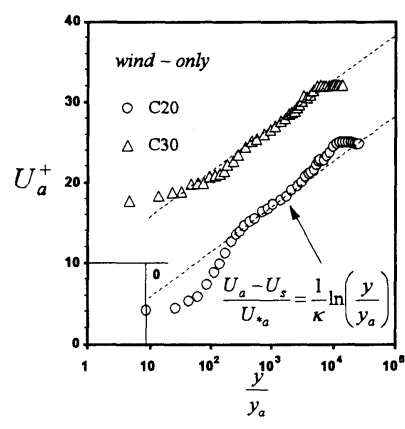

図-4 風波場の空気層平均風速 $U_{a}$ (粗面表示)

(C30 のデータは縦軸を 10 ずつ上方へ 平行移動して表示)

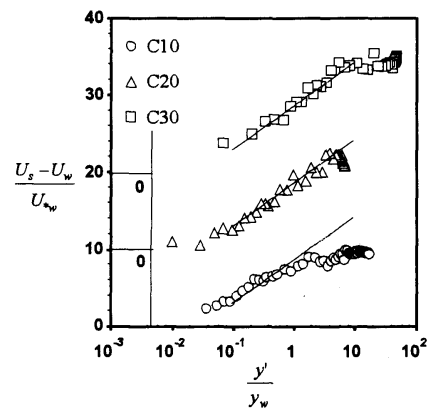

図一（b）風波場の水層平均流速 $U_{w}$ (デー夕は10ずつ上方人平行移動)

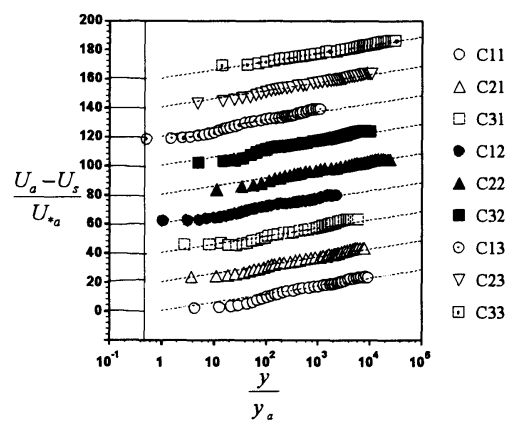

図-5 混成場の空気層平均風速 $U_{a}$ (粗面表示)

(各データは20ずつ上方へ平行移動)

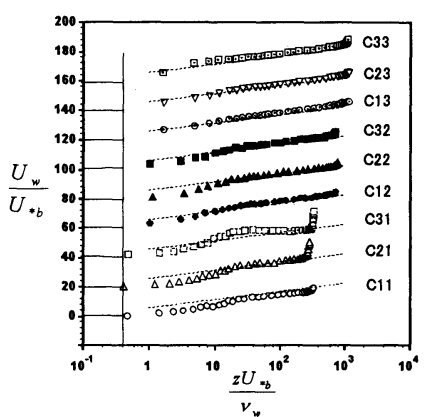

図-7 混成場の水層平均流速 $U_{w}$ (各デー夕は20ずつ上方へ平行移動)
て水路勾配を変化させた. 一方, 風波流れにおいては最 大風速 $U_{a, \max }$ を 3 通り変えて, 水面状態を(1滑面, (2)さ ざ波, (3) 2 次元重力波と変化させた. これらの組み合わ せによって, フルード数 Fr を 3 通り, 最大風速 $U_{a, \max }$ を 3 通り変化させて，合計 9 通りの混成場を設定した.

表-1 において $B$ は水路幅 $(B=40 \mathrm{~cm}), Q$ は水の流量を 示し, $U_{*_{a}}, U_{*_{w}}$ は空気層界面および水層界面での時間平 均流速に対数則分布を適用して求めた界面摩擦速度であ る. また, $U_{*_{b}}$ は水層の平均流速に対数則を適用して求 めた水路底面摩擦速度である.

\section{3. 平均流特性}

図-3は風波場 Case-C10，C20における空気層の主流速 $U_{a}$ の分布を示す. ただし，ケース C200データは図中で 上方に10だけ平行移動させている. 図中には，次式の滑 面対数則および粘性底層における線形式を併示した。

$$
\begin{gathered}
U_{a}^{+} \equiv \frac{U_{a}-U_{s}}{U_{*_{a}}}=\frac{1}{\kappa} \ln \left(\frac{y U_{*_{a}}}{v_{a}}\right)+A \\
U_{a}^{+} \equiv \frac{U_{a}-U_{s}}{U_{*_{a}}}=\frac{y U_{*_{a}}}{v_{a}}
\end{gathered}
$$

ここで, $v_{a}$ は空気の動粘性係数， $\kappa$ はカルマン定数, $A$ は積分定数を示す. 開水路乱流では $\kappa=0.41, A=5.3$ が 推奖值である ${ }^{10)}$. 式(1) は風波場空気流に関して $\mathrm{Wu}^{11)} に$ よって理論的に示されている. 同図より，Aの最適值は 若干変化するが, 風速が弱い場合には滑面対数則が風波 上の空気層で成立することがわかり，W(11)や中山・襧津 ${ }^{8}$ の結果と一致する. 一方, 図-4には風波場 Case-C20, C30における空気層の主流速 $U_{a}$ の分布を示した. ただし， ケース C30のデータは図中で上方に10だけ平行移動させ ている. 図中には次式の粗面対数則を併示した.

$$
U_{a}^{+} \equiv \frac{U_{a}-U_{s}}{U_{* a}}=\frac{1}{\kappa} \ln \left(\frac{y}{y_{a}}\right)
$$

ここで, $y_{a}$ は空気層での粗度高さであり, 平均風速分布 より算定される．図-4より，風速の増大 $(\mathrm{C} 20 \rightarrow \mathrm{C} 30)$ とと もに空気層界面近傍 $\left(y / y_{a}<10^{2}\right)$ では風速勾配が小さくな り，移動境界層の流速分布特性が現れるようである. 図一 5は混成場の風速分布を粗面表示で示す.ただし，ケース C11以外のデータは図中で上方に20ずつ平行移動させてい る. 同図より水流と空気流の混成場でも $y / y_{a}=10^{2} \sim 10^{4}$ 付近で対数則が成立することがわかる. 一方, 界面近傍 では水流と空気流の相対的な局所速度に応じて流速分布 が低減し，粘性効果が現れるようである. 


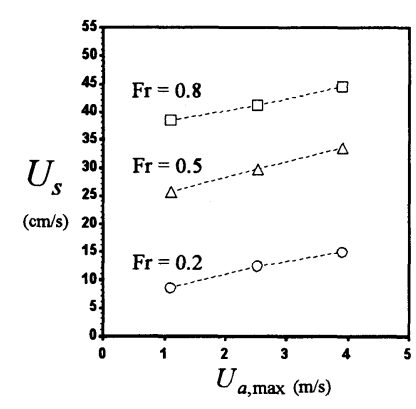

図-8 表面流速 $U_{s}$

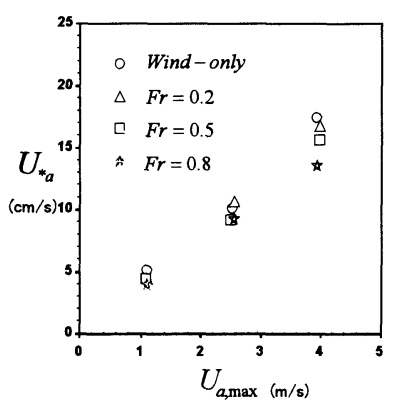

図-9 空気層界面摩擦速度 $U_{*_{a}}$

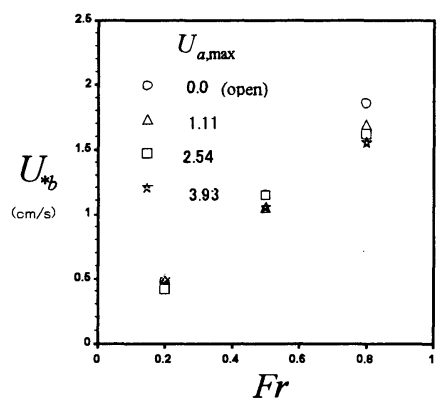

図-10 水層底面摩擦速度 $U_{* b}$

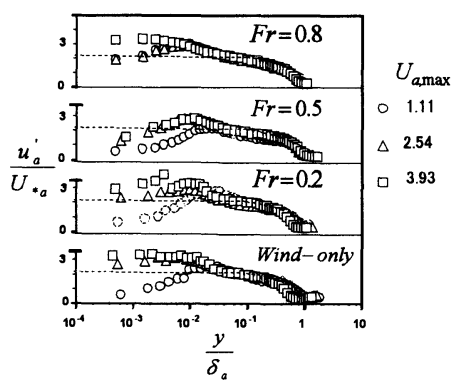

図-11 空気層の乱れ強度 $u^{\prime}{ }_{a}$

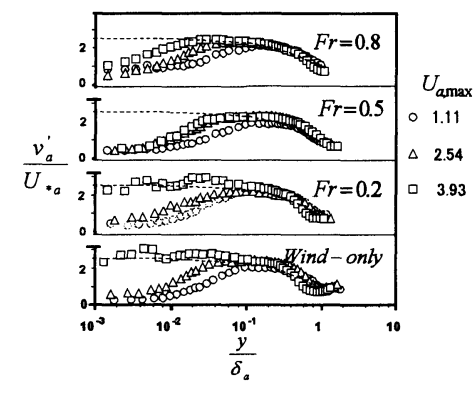

図-12 空気層の乱強度 $v^{\prime}{ }_{a}$

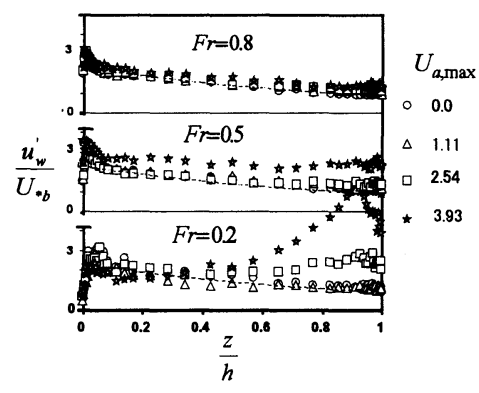

図-13 水層の乱れ強度 $u^{\prime}{ }_{w}$
図-6 (a) は開水路単相流れ（CO1, CO2, C03）における水 層平均流速 $U_{w}$ 分布を, 図一 $6(\mathrm{~b})$ は風波流れ $(\mathrm{C} 10, \mathrm{C} 20$, C30）における $U_{w}$ 分布を，また，図一7 は混成場におけ るU $U_{w}$ の分布を示した. ただし，データは図6で上方に 10 ずつ, 図7 で上方に 20 ずつ各々平行移動させている. 図中には次式の対数則を直線で併示した.

$$
\text { 開水路底面対数則 } \frac{U_{w}}{U_{* b}}=\frac{1}{\kappa} \ln \left(\frac{z}{h}\right)
$$

$$
\text { 風波場界面対数則 } \frac{U_{s}-U_{w}}{U_{*_{w}}}=\frac{1}{\kappa} \ln \left(\frac{y^{\prime}}{y_{w}}\right)+8.5
$$

ここで， $U_{* b}$ は水路底面における摩擦速度， $y^{\prime} \equiv-y ， ま$ た， $y_{w}$ は水層界面粗度高さである ${ }^{12)}$. 式(5)は Shemdin ${ }^{13)}$ による半理論式である. 同図より, 開水路場および混成 場では底面から対数則がほぼ成立し，風波場では Wu ${ }^{11)}$ 加藤ら ${ }^{14)}$ が指摘するように，界面近傍では界面からら対数 則が成立することがわかる. しかし， Fr = 0.2 の混成場 界面近傍では流速は急激に増大し対数則からずれる.こ れは，風による界面シアーが水層界面近傍で卓越してお り底面の影響を受けないためと考えられる.

図-8には混成場表面流速 $U_{s}$ を示した. 同図より， $U_{s}$ はフルード数Fr が一定のときほぼ線形に増加し，例えば 風速が $1(\mathrm{~m} / \mathrm{s})$ から 4 倍になると， $U_{s}$ は $10(\mathrm{~cm} / \mathrm{s})$ 程度増大 する. 一方, 最大風速が一定のとき, 水流が増加して Fr が増加すれば $U_{s}$ は増大する. 例えば，最大風速が $1(\mathrm{~m} / \mathrm{s})$ のとき Fr が 0.2 から 4 倍増吅すれば $U_{s}$ は $30(\mathrm{~cm} / \mathrm{s})$ 程度
増大する. よって, 空気流よりも水流の方が表面流速に 及ぼす影響が大きいことが推察される.

図-9 は最大風速 $U_{a, \max }$ に対して空気層界面摩擦速度 $U_{*_{a}}$ を, 図-10 はまたフルード数Fr に対して水層底面摩 摖速度 $U_{*_{w}}$ を示した. 両図より, 摩擦速度は最大風速と フルード数に比例していることがわかる. 最大風速が同 じ場合ではフルード数が大きいほどU $*_{a}$ は若干減少する. 一方, 同じフルード数の場合には最大風速が大きいほど 底面での摩擦速度 $U_{* b}$ が減少する. これは，界面シアー により底面からの水層流速分布が影響を受けることを示 している.

\section{4. 乱れ特性}

図-11, 図-12 は風波場(Wind-only)およひ混成場における 空気層の流下方向乱れ強度 $u^{\prime}$ およひ鉛直方向乱れ強度 $v^{\prime}$ の分布を $U_{*_{a}}$ で無次元化してそれぞれ示す. また，図中 の点線は次の開水路乱流の普遍関数式 ${ }^{10)}$ (界面近傍除 く）である.

$$
\begin{aligned}
& \frac{u_{a}^{\prime}}{U_{*_{a}}}=2.3 \exp \left(-y / \delta_{a}\right) \\
& \frac{v_{a}^{\prime}}{U_{*_{a}}}=1.27 \exp \left(-y / \delta_{a}\right)
\end{aligned}
$$




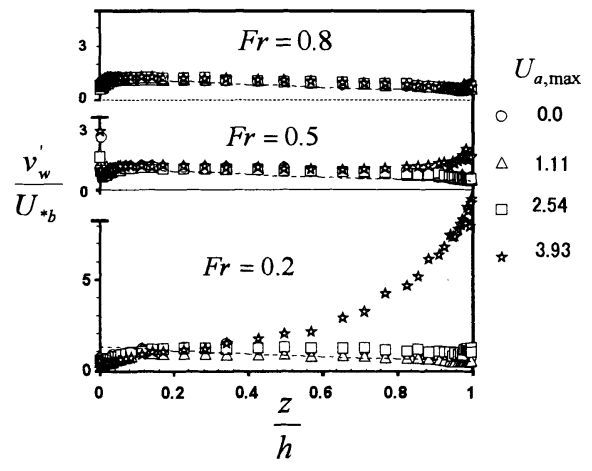

図-14 水層の鉛直方向乱れ強度 $v^{\prime}{ }_{w}$ の分布

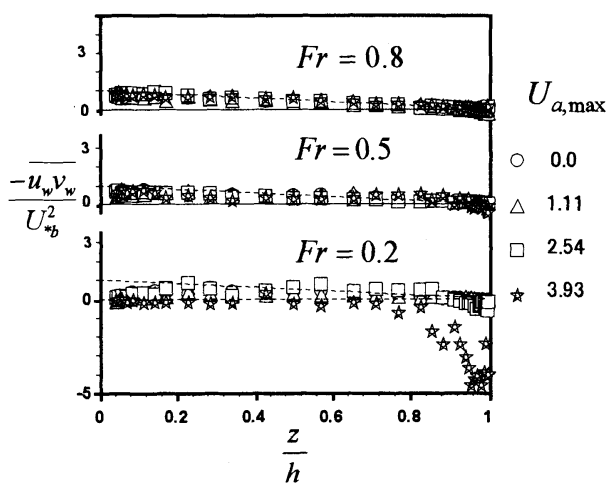

図-16 水層のレイノルズ㐫力 $\overline{u_{w} v_{w}}$ の分布

ここで， $\delta_{a}$ は空気層乱流境界層厚であり，レイノルズ応 力がゼロとなる界面からの距離を示寸，同図より，界面 近傍を除くと空気層乱れ強度はほぼ普遍関数に従うこと がわかる. 一方, 界面近傍では風速が大きくかつ水層流 速 $(F r)$ が小さい時には乱れは減衰しないようである．同 様に，図-13 および図-14 には開水路場(OPEN)および混 成場における水層の流下方向乱れ強度 $u^{\prime}{ }_{w}$ および鉛直方 向乱れ強度 $v_{w}{ }_{w}$ の分布を示した. また，図中に式(6)およ び式(7)を点線で併示した．同図より，風速が弱い場合に は開水路流れにおける乱れの普遍関数によく従うことが わかる. 一方, 水層流速に比へてて相対的に風速が大きく なると，界面近傍で乱れ強度は増大寸る。これは，Hunt

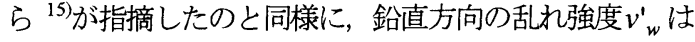
後述の界面変動特性と相関が大きいことを示唆している.

図-15 および図-16 は空気層および水層のレイノルズ応 カー $\overline{u_{a} v_{a}}$ および- $\overline{u_{w} v_{w}}$ の分布を示した. ただし, 次式 の三角形分布も点線で併示した.

$$
\begin{aligned}
& \frac{-\overline{u_{a} v_{a}}}{U_{*_{a}}^{2}}=\left(1-y / \delta_{a}\right) \\
& \frac{-\overline{u_{w} v_{w}}}{U_{*_{b}}^{2}}=(1-z / h)
\end{aligned}
$$

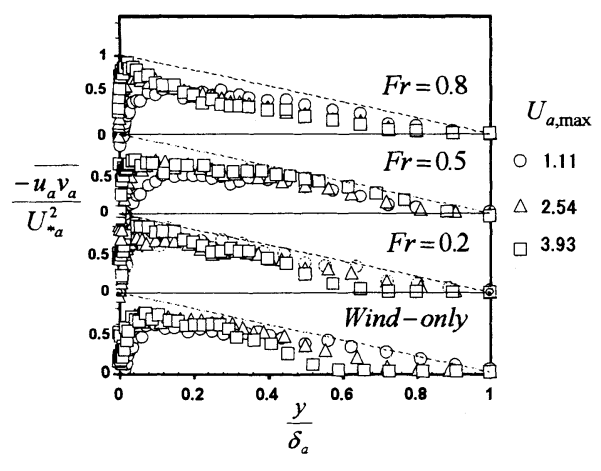

図-15 空気層のレイノルズ忘力 $-\overline{u_{a} v_{a}}$ の分布

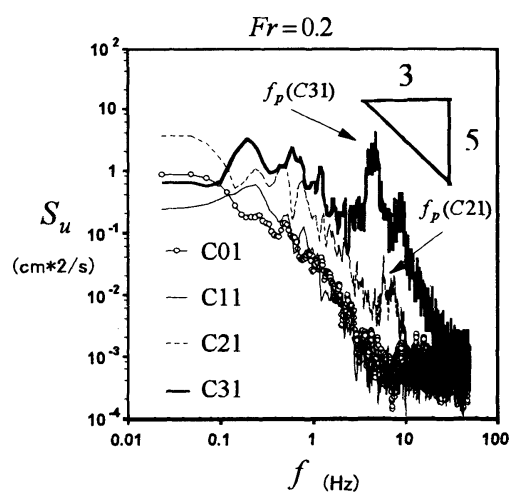

図-17 流速のパワースペクトル $S_{u}(f)$

図-15 より，界面近傍（ $y / \delta_{a} \leq 0.1 ）$ を除いて空気層レ イノルズ応力は式(8)に従うが，界面近傍では三角形分布 より減少する.これは粘性効果であり空気流力ら水流へ と運動量が輸送されていると考えられる. 一方, 図-16 より界面近傍（ $z / h \geq 0.95 ）$ を除いて水層レイノルズ応 力はほぼ式(11)に従う. しかし， Fr $=0.2$ で最大風速が 増大すると, 界面近傍でレイノルズ応力 $-\overline{u_{w} v_{w}}$ は負值 となり, 注目される.この結果は既往の研究では指摘さ れておらず，この理由を以下では考察する.

図-17 はFr=0.2 のケース(CW31)における界面近傍の 流速変動 $u(t)$ から求めたパワースペクトル $S_{u}(f)$ を示寸. また，図-18 には同計測点において風速が最も大きな場 合の流速 2 成分変動 $(u, v)$ の位相差 $\theta_{u v}(f)$ を示した.

図-17 の $f_{p}$ は $1 \sim 10 \mathrm{~Hz}$ 周波数域における風波固有の卓越 周波数を示す．計算には高速フーリエ変換(FFT)を用いた. また, $\theta_{u v}=\pi / 2$ は微小振幅波理論における流速変動の 位相差 (一定値) であり, 図-18 に併示した.

図-17 より風速が増大すると, 界面近傍の流速変動は 風波固有の卓越周波数 $f_{p}$ 近傍で増大し, 風波場での変動 之同様の特性 9)を示す。逆に，風速が弱い場合には界面 近傍でも流速変動は開水路単相流によるものと同一であ 


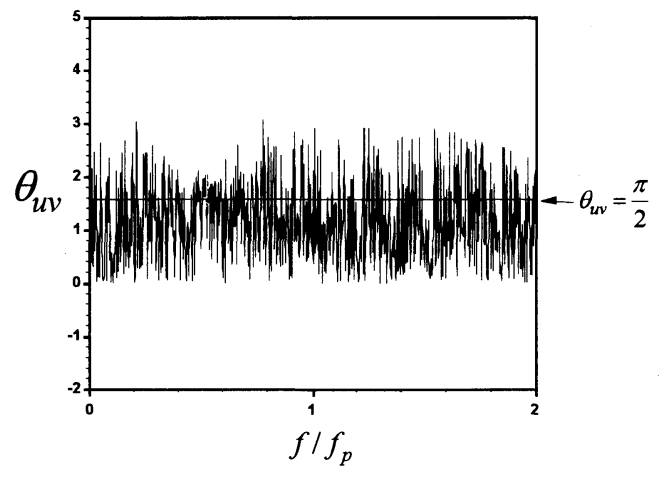

図-18 流速変動位相差 $\theta_{u v}$ (Case: C31)

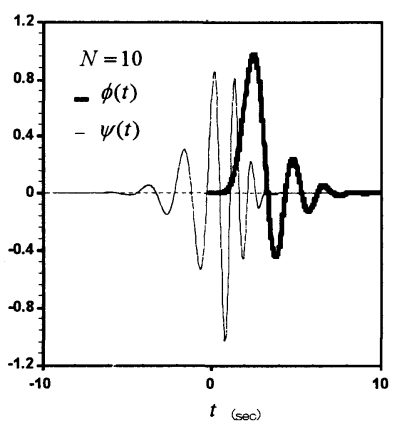

図-20 ウェーブレット関数とスケーリング関数

る.

図-18 より卓越周波数近傍で位相差 $\theta_{u v}$ は平均的に線形 解 $(\pi / 2)$ よりも小さな值を示す，すなわち，これは大き な変動パワーをもつ卓越周波数近傍で 2 成分 $(u, v)$ の流速 変動の位相が同位相に近く, $\overline{u v}>0$ となる. つまり, レ イノルズ応力ー $\overline{u v}$ は負值になることがわかる. したがっ て，界面シアーが卓越した流れ場ではレイノルズ応力は 界面近傍で負值となると考えられる。

\section{5. せん断応力の特性}

図-19 はFrに対して界面せん断応力 $\tau_{s}$ と底面せん断 応力 $\tau_{b}$ の比を示寸. $\tau_{s} / \tau_{b}$ は次式で算定した.

$$
\frac{\tau_{s}}{\tau_{b}}=\frac{\rho_{a} U_{*_{a}}^{2}}{\rho_{w} U_{*_{b}}^{2}}
$$

ここで, $\rho_{a}, \rho_{w}$ はそれぞれ空気層, 水層の密度である. $\tau_{s} / \tau_{b}$ が大きい場合(C21,C31)には先述のように風シアー の影響で水層内での乱れ構造が通常の開水路単相流と異 なり, このことから, せん断応力比 $\tau_{s} / \tau_{b}$ と乱流構造と の関連性が示唆される.

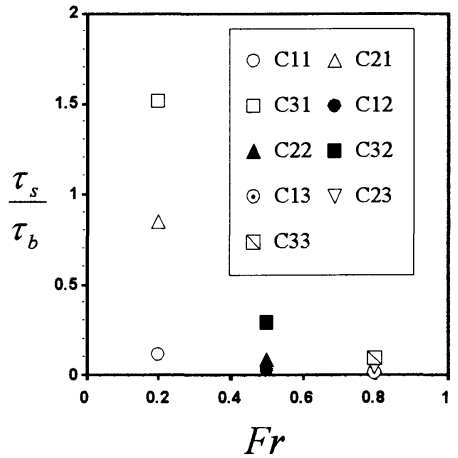

図-19 せん断応力比 $\tau_{s} / \tau_{b}$

さて, Hughes \& Duffey ${ }^{7)}$ は混成場における水層内の流速 分布やせん断応力分布を理論的に算定した. 彼らはせん 断応力を直線分布, 混合距離を放物線分布と仮定して流 速分布を算定した. このとき, せん断応力に関しては次 式の線形和を提案した.

$$
\tau(z) \equiv \mu \frac{\partial U_{w}}{\partial y}-\rho_{w} \overline{u_{w} v_{w}}=\tau_{b}\left(1-\frac{z}{h}\right)+\tau_{s} \frac{z}{h}
$$

一方，先述のように空気流速が大きくなるとレイノル ズ応力が負值となり，水層せん断応力 $\tau$ は次式で示す開 水路単相場での三角形分布を示さないことが予測される。

$$
\tau(z) \equiv \mu \frac{\partial U_{w}}{\partial y}-\rho_{w} \overline{u_{w} v_{w}}=\tau_{b}\left(1-\frac{z}{h}\right)
$$

そこで, 本研究ではLDA 流速変動から卓越した波動成分 を除去した後の乱れ本来の変動のみからレイノルズ応力 を算定してみる.

流速変動に対するフィルタ関数として, 本研究では図一 20 に示すような Daubechies の正規直交離散マザーウェー

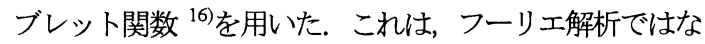
くウェーブレット解析を適用して時間周波数解析を可能 にし，乱れ統計量を精度良く算定するためである. 図中 には $N=10$ におけるウェーブレット関数 ${ }_{10} \psi(t)$ およびそ のスケーリング関数 ${ }_{10} \phi(t)$ を示した. 流速変動成分 $u(t)$ は以下のように展開される.

$$
\begin{gathered}
u(t) \cong u_{0}(t)=\sum_{k=-\infty}^{\infty} c_{k}^{(m)} \phi_{m k}(t)+\sum_{j=m}^{-1} \sum_{k=-\infty}^{\infty} d_{k}^{(j)} \psi_{j k}(t) \\
u_{0}(t)=u_{m}(t)+\sum_{j=m}^{-1}{u^{\prime}}_{j}(t)
\end{gathered}
$$

ここで, $c_{k}^{(m)}$ は離散スケーリング展開係数， $d_{k}^{(j)}$ は離散 ウェーブレット展開係数であり， $u_{0}$ は再構築後の近似流

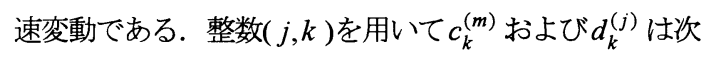
式で算定できる. 


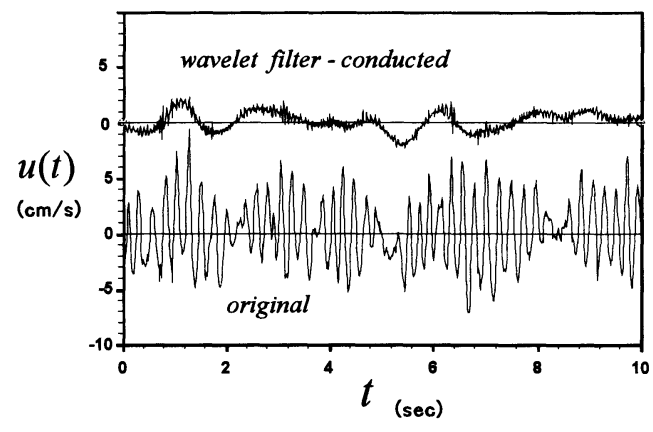

図-21 オリジナル流速変動と Filter-pass 後の流速変動

(Case-C31, $z / h=0.8$ )

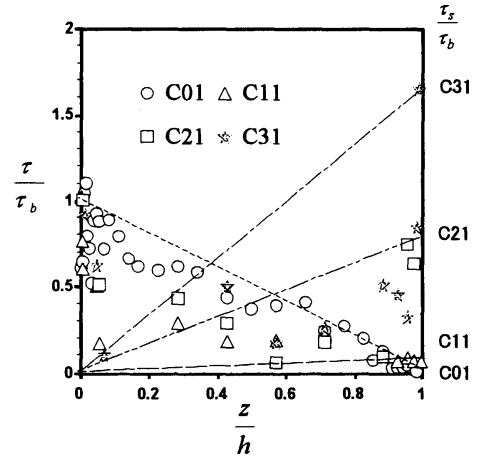

図-22水層せん断応力 $\tau$

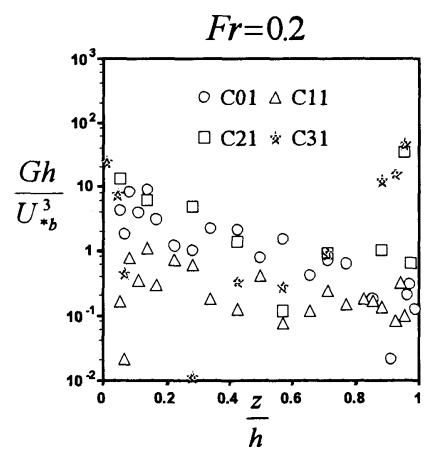

図-23 乱れ発生率 $G$

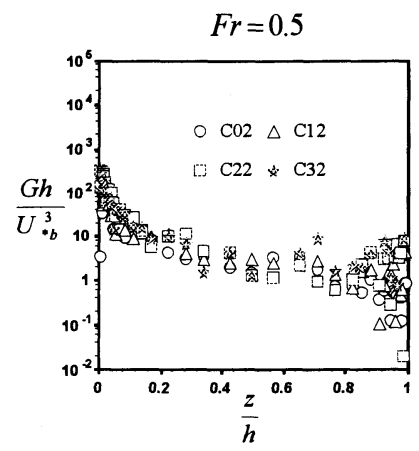

図-24 乱れ発生率 $G$

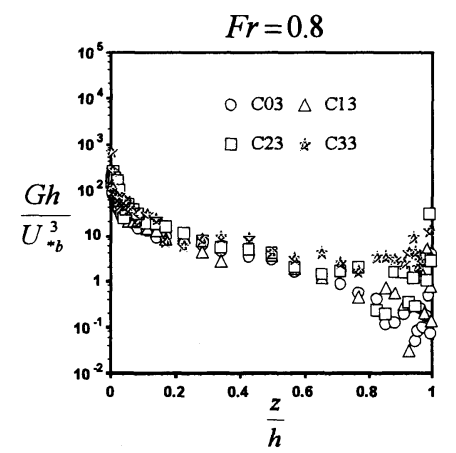

図-25 乱れ発生率 $G$

$$
\begin{aligned}
& d_{k}^{(j)}=2^{j / 2} \int_{-\infty}^{\infty} u(t) \overline{\psi_{j, k}} d t \\
& c_{k}^{(j)}=\int_{-\infty}^{\infty} u(t) \overline{\phi_{j, k}} d t
\end{aligned}
$$

ただし，通常，離散化は次式で示す 2 のベキ乗で行う.

$$
\begin{aligned}
& \psi_{j, k}=\psi\left(2^{j} t-k\right) \\
& \phi_{j, k}=\phi\left(2^{j} t-k\right)
\end{aligned}
$$

ここで， $j$ はレベルと呼ばれ， $j=-1 〜-m(m$ は正の整 数で計測時間に依存する)の範囲で変化する.

図-21 には図-17 で示した水層流速変動の中で最も風速 が大きいケース(C31)に関して，オリジナル時系列 (Original)と Wavelet filter により波動成分 $(1 \sim 10 \mathrm{~Hz}$ 変動, 図-17 参照)のみを除去したフィルタ化時系列(filterconducted)を示した. 同図より，図-17 のスペクトルで示 されたと同様に，波動成分は界面近傍で大きなパワーを 有することが確認される.

図-22 はFr=0.2 における混成場水層の流速変動から 上記 filter 演算後, 次式から算定された水層せん断応力 $\tau$ を求めて示した.

$$
\tau(z)=\mu \frac{\partial U}{\partial y}-\left.\rho_{w} \overline{u_{w} v_{w}}\right|_{\text {filtered }}
$$

同図より，開水路場(C01)ではせん断応力は三角形分布 をするが，風シアーが卓越する際には水層内部では下に 凸な放物線に近い分布を示すことがわかる.

このことより，混成場での仮定は成立しないことがわ かる. 一方，底面シアーが卓越する他のケースではせん 断応力分布は既往の研究結果と一致し，せん断応力は界 面を除いてほぼ三角形分布を示すことがわかった。

\section{6. 乱れエネルギ一特性}

図-23〜25には水層における乱れエネルギー発生率 $G$ を 示した. $G$ の值は次式で算定でき, 水深 $h$ と底面摩擦速 度 $U_{* b}$ で無次元化して図示した.

$$
G \equiv-\overline{u v} \frac{\partial U}{\partial y}
$$

ただし，レイノルズ応力が負值となる場合には先述の波 動成分を除去するフィルタを施した後に算定した. 図よ 


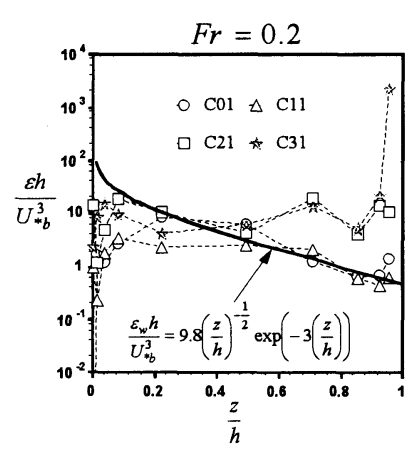

図-26 乱れ逸散率 $\varepsilon$

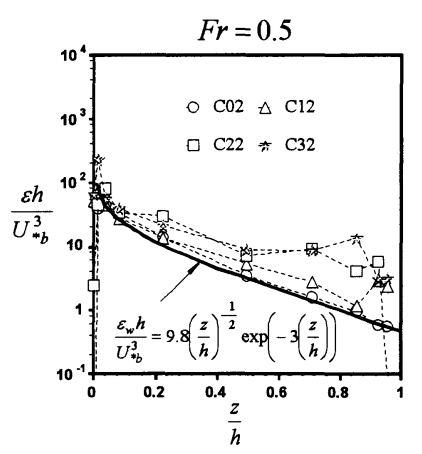

図-27乱れ逸散率 $\varepsilon$

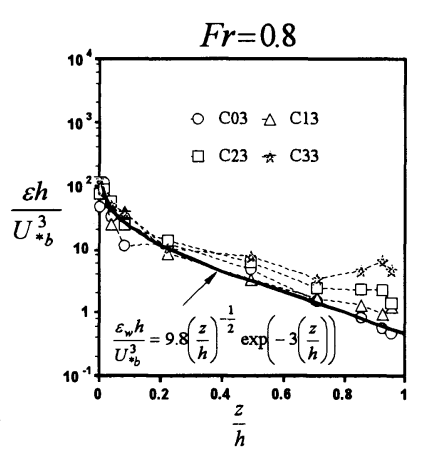

図-28 乱れ逸散率 $\varepsilon$

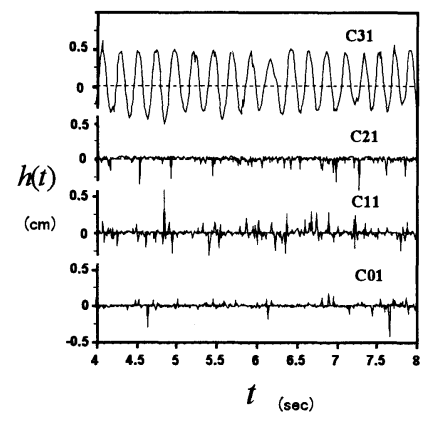

図-29 水面変動の時系列 $h(t)$

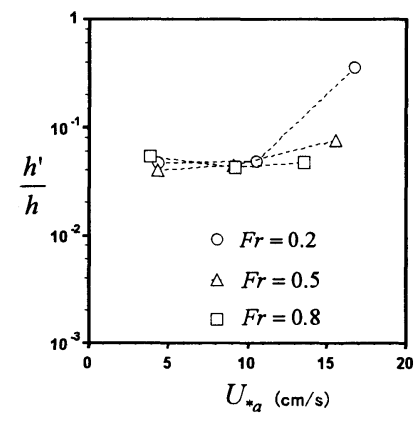

図-30 水面変動強度 $h^{\prime}$
り，底面シアーおよび界面シアーに対応して，底面近傍 および界面近傍にて乱れは発生することがわかる.

一方，図-26 28には水層における乱れ逸散率 $\varepsilon$ を示し た. $\varepsilon$ の值はスペクトル分布で慣性小領域の-5/3乗則を確 認した後, 次式で算定して, 無次元化して図示した.

$$
\varepsilon=\frac{U}{2 \pi}\left(\frac{1}{C} f^{5 / 3} S_{u}(f)\right)
$$

ここで, $U$ は算定点における平均主流速 $U_{w}$ で近似し, $C$ はコルモゴロフ定数 $(=0.5)$ である. なお，図中には襧津 の普遍関数10)を示した.

$$
\frac{g h}{U_{* b}^{3}}=9.8\left(\frac{z}{h}\right)^{-\frac{1}{2}} \exp \left(-\frac{3 z}{h}\right)
$$

図より，風速が増大寸るにつれて乱れ逸散率は界面近傍 にて増大することがわかる．また，低フルード数ほどそ の傾向が大きい. 乱れ発生率 $G$ と逸散率 $\varepsilon$ とを比較する と，底面近傍では発生率が逸散率よりも卓越するが，一 方, 水層内部や界面近傍では風シアーと底面シアーの相 対的な大きさによって乱れの発生と逸散の大小が変化す ることがわかり，乱れエネルギーの収支関係に底面シア 一と界面シアーが深く関与することが推測される.つま り，界面シアーが相対的に大きい場合には界面で乱れは 発生し水層内部では逸散率が大きくなる. 逆に界面シア 一が相対的に小さい場合には界面で乱れは逸散し水層内
部では乱れは平衡状態になり, 開水路単相流れにおける 乱れエネルギー収支関係と同様の特性となる.

\section{7. 水面変動特性}

図-29には $F r=0.2$ における開水路場および昆成場にお ける水面変動時系列 $h(t)$ を示す. 図-30は空気層界面摩擦 速度 $U_{*_{a}}$ に対して水面変動強度 (水面変動の $\mathrm{ms}$ 值) $h^{\prime}$ を示す.ここで，図中にて $h$ は時間平均水深を示す，同 図より, 水面変動は風速に応じて増大するとは限らず, 水流と空気流の相対的な速度に応じて変化するようであ る.

図-31〜33には開水路場および混成場における水面変動 $h(t)$ と水層界面近傍流速変動 $u(t), v(t)$ との相関係数 $\hat{C}_{u h}, \hat{C}_{v h}$ を遅れ時間 $\tau$ に対して示す. ただし, 流速変動 の計測点は $z / h \cong 0.9$ であり, 水面変動の計測点は流速変 動計測点の鉛直上方である. C31のケースでは超音波の乱 反射により水面変動と流速変動の同時計測が困難であり, データを掲載していない，同図より，水面変動が小さな 場合には $\hat{C}_{u h}<0, \hat{C}_{v h}>0$ であり, 正の水面変動 $h(t)(>0)$ の時には $u(t)<0 か つ v(t)>0$ となり, 水面における局所的 な流体の連続性が満足されている. 一方, 水面変動が大 


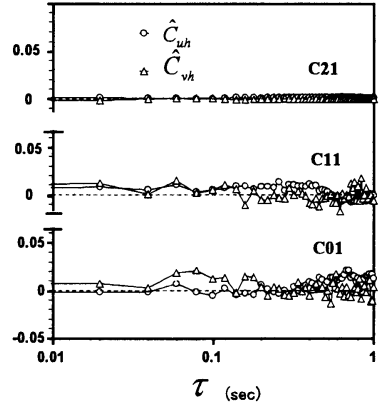

図-31 水面変動と流速変動の相関係数 $\hat{C}_{u h}, \hat{C}_{v h}(F r=0.2)$

きくなると， $\hat{C}_{u h}, \hat{C}_{v h}$ はともに正の值を有する.これは 先に示したように界面近傍流体の位相差が小さくなり水 面変動と同一の組織的な変動をするからであると考えら れる.

\section{8. 結論}

本研究は水面上に風シアーが存在する開水路流れ場 （水・空気 2 層流）を対象として，両層をレーザー流速 計(LDA)で 2 次元計測を行い，その乱流構造に関して実験 的に検討をしたものである. 主要な結果は以下のとおり である.

1) 水層・空気層ともに底面から，および界面からほぼ対 数則が成立する. 界面近傍の粘性底層の存在は界面形状 に依存する.

2) 空気層の乱れ分布は開水路等流に関する普遍関数がほ ぼ適用できる. 界面近傍での乱れの変化特性は界面形状 による，一方，水層乱れ強度は風シアーが弱い場合には 開水路普遍関数が成立するが，風シアーが強まると界面 近傍で急激に増大してずれる.これは主に波による乱れ の誘発と考えられる.

3) 水層・空気層ともにレイノルズ応力はほぼ二角形分布 を示すが，空気層では界面近傍で運動量輸送のために減 少し，水層では界面近傍で波による影響を受けるために 負值を有する．一方，水層におけるせん断応力はほぼ三 角形分布を示すが，風シアーが強まる場合には下に凸な 放物線状の分布を示寸。

4) 乱れエネルギーの発生率と逸散率の比を考察すると, 界面シアーが弱、場合には界面近傍では乱れは逸散し， 水層内部では平衡状態である. 一方, 界面シアーが卓越 すると，乱れは界面でも発生し，水層内部では逸散する。 5) 水面変動強度は水・空気流の相対速度に大きく依存す る. 水面変動と水層界面近傍の流速 2 成分変動との相関
係数は，底面シアー卓越条件では正值と負値をとり，界 面シア一卓越条件ではともに正值をとることがわかった.

謝辞 : 本研究は科学研究費補助金基礎研究(B)課題番号 12450200 (研究代表者 : 襧津家久) のもとで遂行された ことを記し，これに感謝する。

\section{参考文献}

1) 道奥康治, 辻本剛三, 宮本仁志 : 吹送密度流の流動・混合特 性，水工学論文集，第 37 巻, pp293-298, 1993.

2) 新谷哲也，梅山元彦 : 風応力下における閉鎖二成層水域内で の中間密度層の混合特性，水工学論文集，第 44 巻, pp.981-986, 2000.

3) Komori, S., Nagaosa R. and Murakami, Y.: Turbulence structure and mass transfer across a sheared air-water interface in wind-diven turbulence, J. FluidMech., Vol249, pp.161-183, 1993.

4) Riley, D.S., Donelan, M.A. and Hui, W.H: An extended Miles' theory for wave generation by wind, Borndary Layer Meteo., No.22, pp.209225,1982

5) Reid, RO: Modification of the quadratic bottom-stress law for turbulent channel flow in the presence of surface wind-stress, Tech. Memo., No.93, Beach Erosion Board U.S. Corps of Engineers, 1957.

6) 鶴谷広一: 海域における乱れと物質輸送に与える風の効果に 関する研究。東京工業大学学位論文, 1987.

7) Hughes, E.D. and Duffey, R.B.: Direct contact condensation and momentum transfer in turbulent separated flows, J. Multiphase Flow, Vol.17, No.5, pp.599-619,1991.

8) 中山忠暢・螎津家久: 水・空気 2 層流の乱流構造について, 土木学会論文集 No.670/I-54, pp.1-12,2001.

9) 襧津家久，吉田圭介，池田大輔，水・空気層の同時計測によ 万風波界面近傍流体の相関構造に関する研究，水工学論文集 第 46 巻, pp.547-552, 2002 .

10) Nezu, I. and Nakagawa, H: Turbulence in Open-Channel Flows, IAHR-Monograph, Balkema, 1993.

11) Wu, J.: Wind-induced drift currents, J. FluidMech, Vol68, pp.49-70, 1975.

12）禰津家久, 中山忠暢, 井上理恵: 風波発生下における水・空 気界面での乱流構造に関する研究，水工学論文集, 第 43 巻, pp.413-418, 1999 .

13) Shemdin, O.H.: Wind-generated current and phase speed of wind waves, J. Physical Ocean., No.2, pp.411-419, 1972

14) 加藤始, 大島直樹, 信岡尚道 : 画像流速計を用いた吹送流の 鉛直分布に関する実験的研究, 海岸工学論文集, 第 47 巻, 
pp.241-245, 2000

15) Hunt, J.C.R and Graham, J.M.R: Free-stream turbulence near plane boundaries, J. Fluid Mech., Vol.84, pp.209-235, 1978.

16)Daubechies, I: Ten lectures on wavelets, SIAM, Philadelphia, 1992.

\title{
A FUNDAMENTAL STUDY ON AIR-WATER TURBULENT STRUCTURES IN WIND-INDUCED OPEN-CHANNEL FLOWS
}

\author{
Iehisa NEZU, Keisuke YOSHIDA and Satoru USHIJIMA
}

\begin{abstract}
Two-dimensional (2-D) turbulence measurements of air-water interface in wind-driven open-channel flows were conducted in the center of channel by making use of a laser Doppler anemometer (LDA). As the results, it was found that an air-shear influences largely on interfacial turbulent structures in water flow region. The turbulence intensity is so high up to the water interfacial region. Of particular significance is the large negative value of the Reynolds stress, in the condition that the surface stress due to the air-shear is prior to the water-bed stress.
\end{abstract}

